\title{
First-Year Student Motivations for Service-Learning: An Application of the Volunteer Functions Inventory
}

\author{
Andrew J. Pearl \\ University of North Georgia
}

\author{
Robert K. Christensen \\ Brigham Young University
}

\begin{abstract}
This study extends a line of research focused on motivational factors that contribute to first-year students' reasons for engaging in service-learning. Among first-year students, altruistically-motivated students (Christensen, Stritch, Kellough, \& Brewer, 2015) and minority students (Pearl \& Christensen, 2016) were not only more knowledgeable of service-learning upon entering college but they were also more interested in enrolling in service-learning. The present study employs the Volunteer Functions Inventory (VFI) (Clary et al., 1998) to explore the extent to which student traits are correlated with various motivations to enroll in service-learning courses. We examine student responses to the VFI survey instrument using multiple analysis of variance (MANOVA). Our findings establish a foundation that better accounts for students' "inputs" in order to better understand various service-learning outcomes. We discuss the implications of our findings as they relate to higher education administrators and instructors in order to close the gap between service-learning interest and enrollment, and to provide students with service-learning experiences that satisfy their motivations and help them achieve their goals.
\end{abstract}

A majority of service-learning research has focused on outcomes with relatively less attention paid to students' traits and motivations as antecedents of service-learning. The present study extends a line of research focused specifically on motivational factors that contribute to new students' reasons for engaging in service-learning. Among first-year students, altruistically-motivated students (Christensen, Stritch, Kellough, \& Brewer, 2015) and minority students (Pearl \& Christensen, 2016) were not only more knowledgeable of servicelearning upon entering college, but they were also more interested in enrolling in service-learning. The present study continues this line of exploratory motivations-as-antecedents research by employing the Volunteer Functions Inventory (VFI, Clary et al., 1998) to begin to better understand the extent to which student traits are correlated with various motivations to participate in service-learning. The VFI is a statistically-validated and widely-used instrument originally designed to understand the motivations for general volunteering behavior and the dimensions of those motivations. Bringle, Phillips, and Hudson (2004) recommended the VFI as a potential tool to investigate service-learning students' motivations. We take up that invitation in this paper.

\section{"Inputs" that Support Service- Learning Outcomes}

Service-learning's many benefits have long been documented in the literature through empirical re- search, case studies, program evaluations, and anecdotal evidence. Eyler, Giles, Stenson, and Gray (2001) provide a detailed, annotated bibliography of student outcomes as they relate to students' personal, social, learning, and career development, as well as their relationships to their higher education institutions. In general, the literature summarized by Eyler and her colleagues indicate overall positive outcomes for students in these varied developmental areas. The degree to which students experience positive gains in these areas has been found to be connected to the learning goals identified by instructors, specifically how critical reflection activities are framed and utilized in the course (Einfeld \& Collins, 2008).

More recently, Clayton, Bringle, and Hatcher (2012) edited a volume intended to advance the research on service-learning outcomes by identifying and suggesting theoretical bases through which continued studies could be conducted. Contributors provided detail on theoretical perspectives as they relate to students' cognitive outcomes (Fitch, Steinke, \& Hudson, 2012), academic learning outcomes (Jameson, Clayton, \& Ash, 2012), civic learning (Battistoni, 2012), personal development outcomes (Brandenberger, 2012), and intercultural competence (Deardorff \& Edwards, 2012).

Along with more purposeful inclusion of theoretical frameworks, investigators have also sought to gain a more nuanced understanding of the causal paths that specify how service-learning might affect student outcomes. For example, empirical re- 
search has been conducted to investigate the impact of individual course characteristics on student outcomes (Matthews, Pearl, \& Wilder, 2014; Moely \& Ilustre, 2014). Other empirical evidence suggests that students from diverse backgrounds may experience service-learning courses and the associated outcomes differently (e.g., Chesler \& Vasques Scalera, 2000; Coles, 1999; Green, 2001; Mitchell \& Donahue, 2009).

While a majority of the literature has focused on the environments and outcomes of servicelearning participation, less attention has been given to the "input" part of the equation in Astin's (2012) Input-Environment-Output (I-E-O) model. We argue that factors such as students' traits and motivations are prime candidates to better articulate the "input" landscape. For example, race, gender, socio-economic status, motivation, and previous experiences with voluntary behavior (to name just a few) are too often considered control variables - if considered at all - rather than a central focus of research. We propose that a purposeful investigation of student inputs, including student traits and motivations, is necessary. What, for example, drives students to consider enrolling in service-learning courses? We then can begin to understand more about why particular outcomes occur.

Considering students' "inputs" is an important step because this information could help servicelearning instructors and administrators take a more targeted approach for the recruitment of students to participate in service-learning and community engagement. This, in turn, could create more opportunity for a broader audience to take advantage of service-learning's many potential benefits and provide more insight than simply observing student growth after some process that occurs in a nebulous "black box." Causality is a difficult standard to meet, and some believe that it may be impossible to do in a service-learning context $(\mathrm{Bu}-$ tin, 2006), but the more we understand about the inputs, including student traits and motivations, the better we will be able to connect educational processes to student outcomes. That is the purpose of this exploratory study: to explicitly investigate (a) student race and gender, (b) a variety of motivational dimensions, and (c) their relationships as potentially significant service-learning inputs. We offer brief reviews of literature relevant to these inputs and then describe our data, methods, and findings. We conclude with a discussion that outlines implications of our findings as well as directions for future research.

\section{Individual Traits and Volunteering: Race and Gender}

Scholars who study general volunteering (outside of the service-learning context) document that women and minorities give time and resources differently than men and Whites. For example, women may generally volunteer more than men (Einolf, 2011) but in different domains and rates (see Musik $\&$ Wilson, 2008). The findings concerning race and volunteering are somewhat similar in that Whites may generally donate (e.g., Van Slyke, Ashley, \& Johnson, 2007) or volunteer (e.g., Rotolo, Wilson, \& Hughes, 2010) more than minorities, but there is also evidence that context, solicitation, and incentive mechanisms matter differently to White volunteers compared to minority volunteers (see Laurence, 2009; Van Slyke et al.). Our read of this volunteering literature is that gender and race differences are nuanced and may be contingent upon motivations, resources, incentives, and solicitation.

Voluntary behavior is influenced by an integration of multiple forms of capital (Wilson \& $\mathrm{Mu}$ sick, 1997). Empirical research has demonstrated that individuals with greater levels of human and social capital are more likely to volunteer (Brown \& Lankford, 1992; Bryant, Jeon-Slaughter, Kang, \& Tax, 2003; Mesch, Rooney, Steinberg, \& Denton, 2006; Smith, 2002), and the inverse is also true - lesser levels of human and social capital have been given as reasons for not volunteering (Musick, Wilson, \& Bynum, 2000). Human capital theory would suggest that differences in volunteering and charitable giving between racial and ethnic groups is attributable to differing resources (Mesch et al.); nevertheless, empirical research has suggested that Black volunteers may be more likely to volunteer in general (Van Slyke \& Escholz, 2002).

Fewer studies have explored these patterns in service-learning, but some recent scholarship suggests that among freshmen students at a large public land-grant institution in the southeast, minority students were not only more knowledgeable about service-learning entering college, but they were also more interested in enrolling in servicelearning (Christensen et al., 2015). However, national trends suggest that there remains a significant gap in service-learning enrollment - the majority of students taking service-learning courses are White (Jacoby, 2015).

What then causes this disparity between knowledge of and interest in service-learning and actual service-learning enrollment? Butin (2006) warned against the dangers of service-learning becoming a pedagogy designed to provide an experience primarily for the "Whitest of the White" students, and 
stressed the importance of taking a critical examination of service-learning and purposefully working toward finding a way to make service-learning accessible to all students, not just those who fit the traditional (and outdated) mold of what it means to be a college student. As with the broader volunteer literature, a more nuanced understanding is warranted to better understand surface-level trends.

In a qualitative analysis of open-ended student responses, Pearl and Christensen (2016) found that minority students report that they may be interested in fulfilling different needs through participation in service-learning than White students. In particular, minority students indicate that they are more driven by the public service aspect of service-learning than its academic aspects, suggesting that the gaps in participation rates in service-learning courses may, at least in part, be due to the fact that minority students can fulfill these motivations through other voluntary activities. Further, the academic component of service-learning may, in fact, be perceived as a barrier to service-learning participation if the primary goal of the student is to provide service to the community. Pearl and Christensen (2016) emphasize the importance of initiating conversations related to the differing motivations of students, including how those may relate to gender or race, in order to provide experiences that meet their needs and goals.

\section{The Volunteer Functions Inventory}

Grounded in the classical theoretical foundations of functionalism (i.e., Katz, 1960; Smith, Bruner, \& White, 1956), Clary et al. (1998) developed the Volunteer Functions Inventory (VFI) based on the belief that people may choose to engage in the same voluntary activity for different reasons. Simply put, different individuals may be fulfilling different psychological functions by engaging in the same activity. Through a series of six investigations, Clary et al. tested the validity and reliability of six motivational dimensions or "functions" for volunteering: values, enhancement, understanding, protective, social, and career.

The values function allows individuals to publicly express their values and demonstrate that they have "altruistic and humanitarian concerns for others" (Clary et al., 1998, p. 1517). Through the understanding function, individuals have the opportunity to learn new knowledge, skills, and abilities, as well as have the chance to experience and exercise their existing knowledge, skills, and abilities. The social function relies on the individual's relationships with others, providing volunteers with the opportunity to socialize with their family and/or friends and improve those relationships, meet new friends, and be viewed favorably by others, especially the social groups with which they associate. The career function suggests that volunteers may engage in service to develop, enhance, or maintain their career-related skills in pursuit of their chosen profession. The protective function is one which individuals pursue to protect the ego; for example, volunteering to reduce one's guilt for being more fortunate than others or to work through personal problems. Finally, the enhancement function, which also deals with the individual's ego, seeks to build the ego through motivational processes centering on positive development.

Considering motivational differences by gender, female volunteers generally score higher on the VFI than male volunteers (Fletcher \& Major, 2004; Okun, Barr, \& Herzog, 1998), although in a sample of medical students, men and women demonstrated similar patterns of the relative importance of the six VFI functions (Fletcher \& Major). Einolf (2011) found that although women may be more interested in volunteering and more motivated to engage in prosocial behavior, the resource, skills/education, and social capital advantages of men in many ways offset participatory differences. The literature also contains several examples of VFI investigations among older adults (i.e., Brayley, Obst, White, Lewis, Warburton, \& Spencer, 2014; Okun $\&$ Schultz, 2003), but a specific focus on race (and to some degree gender) thus far has been understudied. Lai, Ren, Wu, and Hung (2013) found that among the six functions of the VFI there was only a significant difference in the enhancement function between actual and potential Chinese volunteers, leading the authors to suggest at least a marginal impact of national identity on voluntary behavior. This may indicate that other elements of identity such as race and gender - may also have an impact on voluntary behavior.

Utilizing the VFI, the motivation to volunteer has been associated with other prosocial behaviors - in this case, organ donation - among a sample of Black individuals (Terrell, Mosley, Terrell, \& Nickerson, 2004). Differing levels of motivation, based on VFI scores, have been shown to be associated with variations in frequency of volunteering (Allison, Okun, \& Dutridge, 2002), in particular with the values function. Satisfaction with volunteering experiences has been found to be positively correlated with fulfillment of five of the six VFI functions, the career function being the exception (Finkelstein, 2008). Finkelstein also found that strongly-held motives were more likely to be fulfilled through an individual's volunteering. Subsequent testing of the VFI instrument has explored the utility of five func- 
tions (excluding the career function) and even three functions (combining the enhancement and protective functions and excluding the career and understanding functions) (Brayley et al., 2014). The research of Brayley et al. further supported previous research that found that the values function was a much greater predictor of sustained voluntary behavior than the social function.

Stukas, Clary, and Snyder (1999) further considered the utility of the VFI, extending its application to service-learning in higher education, particularly the potential functional motivations for students, institutions, and the communities being served. And Bringle et al. (2004) further recommended the VFI as a valuable tool to investigate students' motivations as they relate to service-learning.

Citing Olney and Grande (1995), Stukas et al. (1999) discussed the values function, observing that students often do not have the experience to have fully developed values and attitudes toward social responsibility. Instead, Stukas et al. review the literature that suggests that service-learning can develop prosocial values, although these positive outcomes are largely mediated by the quality of the student's service.

Related to the understanding function, Stukas et al. (1999) review the many ways students understand more about the world, particularly their academic gains, as well as their understanding of themselves and the communities in which they live. The quality of student understanding is largely reliant on the relevance of the service experience to the academic course content, and is facilitated through critical reflection.

Considering the social function, Stukas et al. (1999) suggest that students may elect to enroll in service-learning because they believe that they are expected to do so by the social groups with which they associate, including their families, peers, community leaders, and their institutions. Further, Stukas et al. cite the research that suggests that the relationships between students and instructors may be positively impacted through service-learning.

Because students are often still in the process of determining their future vocations, Stukas et al. (1999) observe that the career function generally comes into play for students as they gauge their potential fit in a particular major or career path, provided that the service activity has a clear connection to the development of knowledge and/or skills needed for a future profession. Stukas and colleagues also make reference to research indicating that service-learning can help students develop intrinsic work values and understand the importance of their future careers and work lives.
Stukas et al. (1999) believe that the protective function is relevant to students engaging in servicelearning because students may enroll in servicelearning to protect themselves from other stresses, reduce feelings of isolation, or improve attendance and behavior. These researchers also cite multiple examples of how service-learning can help students feel more engaged in the college experience, including the potential to improve attendance and reduce disciplinary problems.

Stukas et al. (1999) propose that the enhancement function is relevant to students enrolled in service-learning because these experiences can develop responsibility and autonomy in students as they are given opportunities to make meaningful choices, thereby building their self-esteem and selfefficacy. These researchers acknowledge that personal and situational factors may moderate these self-enhancement outcomes.

Some previous research involving college students has suggested that appealing to individuals' motivations is more likely to lead to successful recruitment of students to get involved in civic engagement initiatives, although the protective and social functions may be the weakest appeals of the six VFI functions (Schatteman, 2014).

Building from the above theoretical and conceptual frameworks, this exploratory study seeks to add to the extant literature by addressing the following two research questions. First, are there significant motivational differences for servicelearning among male and female students? Our hypothesis is that, based on previous research utilizing the VFI among volunteers, female students will express greater levels of motivation to participate in service-learning. Second, are there significant motivational differences for service-learning among White students and minority students? Our hypothesis is that, based on previous research of voluntary behavior (Mesch et al., 2006; Van Slyke \& Escholz, 2002), minority students will express greater levels of motivation to participate in service-learning than White students.

\section{Method}

To explore service-learning inputs of student traits (gender/race) and motivations (volunteer functions), we employ a quantitative analytic method. We examine student responses to a survey adapted from the original Clary et al. (1998) VFI. The student self-reported data are then analyzed using multiple analysis of variance (MANOVA). All analyses were conducted with SPSS. 


\section{Survey Instrument and Sampling Strategy}

We employed a purposive sampling strategy to intentionally include first-year students from multiple semesters, partnering with the institution's Office of Institutional Diversity (OID), Center for Student Organizations (CSO), and two sections of American Government, an introductory political science course that fulfills a general education requirement (the course was not a service-learning course). We sent a cover letter template and links to a Qualtrics survey instrument to the individuals responsible for managing the distribution lists for the above groups; therefore, we do not have access to the full list of students who received the invitation to participate. Therefore, we are unable to report a reliable response rate. Students were incentivized to participate in the survey by entering them into a random drawing for a gift card, and the study was approved by the university's Institutional Review Board (IRB).

Minor modifications were made in the wording of the VFI survey instrument. For example, "servicelearning" replaced "volunteering" throughout. A question was included at the beginning of the survey asking if students were currently enrolled in or had previously taken service-learning at the institution, leading them to differently-worded versions of the survey. The original VFI instrument utilizes a seven-point Likert scale; however, based on previous research that found no reduction in scale reliability and validity, our instrument utilizes a five-point Likert scale (Manud, 2014), where $1=$ Strongly Disagree, 2 = Disagree, $3=$ Neither Agree nor Disagree, $4=$ Agree, and $5=$ Strongly Agree . We also asked students to indicate whether or not they would be more likely to enroll in a servicelearning course or a traditionally taught course. Demographic information was collected related to students' race, gender, age, and socioeconomic status. Finally, to verify that we were surveying freshmen we asked students to indicate the number of semesters they had completed as well as their voluntary and charitable activities outside of their coursework. To provide guidance for students who were not previously familiar with service-learning, we provided a simple, introductory definition (see the Appendix to view the wording for each of the VFI items, both for the students who were either currently enrolled in or had previously taken servicelearning courses as well as the students who had no previous experience with service-learning). The descriptive statistics for the student responses are also provided in Appendix A.

\section{Analytic Methods}

Data were analyzed using multiple analysis of variance (MANOVA), a statistical technique used to test for differences in means between two or more groups, examining multiple dependent variables (e.g., multiple functions/dimensions of service-learning motivations). Huberty and Petoskey (2000) identify multiple perspectives on the purpose for conducting a MANOVA, and indicate the preferred purpose is to better understand the effect of at least one independent (or grouping) variable on the outcome variables, a recommendation we follow in this study. In this study, we examined six outcome variables to correspond to the six functions of the VFI (protective, values, career, social, understanding, and enhancement). As a means of data reduction, composite variables were derived for each of the six functions of the VFI using factor analysis prior to analysis. Using Chronbach's $\alpha$, we analyzed the reliability of the six composite variables. As shown in Table 1, acceptable or good levels were met for each of the composite variables (Tavakol \& Dennick, 2011).

Two variables were selected as grouping variables: students' self-reported race and students self-reported gender. In our sample of 130 students, only a small number $(n=58)$ identified themselves in various racial minority groups; therefore, respondents were re-coded to be either White or Racial Minority. Those included in the Racial Minority group identified themselves in the survey as either Hispanic/Latino, American Indian/Alaska Native, Asian, Black/African-American, Hawaiian/Pacific Islander, and/or Multiracial. We fully acknowledge

Table 1

Internal Reliability

\begin{tabular}{lcc}
\hline VFI Function & Chronbach's $\alpha$ (previous SL) & Chronbach's $\alpha$ (no previous SL) \\
\hline Career & 0.766 & 0.801 \\
Social & 0.834 & 0.778 \\
Values & 0.883 & 0.832 \\
Enhancement & 0.822 & 0.826 \\
Protective & 0.790 & 0.780 \\
Understanding & 0.871 & 0.856 \\
\hline
\end{tabular}


that this is an overly reductive view of race; however, this was necessary for the purposes of our analyses given our sample size.

Through qualitative analysis, Pearl and Christensen (2016) found that minority students may be interested in fulfilling different needs by enrolling in service-learning than White students. Consequently, the first model we ran includes only race as a grouping variable, the second model includes gender as a single grouping variable, the third model includes both race and gender as grouping variables, and the final model adds the interaction of race and gender as a grouping variable.

\section{Results}

In the following section, we discuss the MANOVA findings. As a means of providing guidance for the interpretation of our findings, we will be presenting the results of the multivariate tests and the tests of between-subjects effects. First, the multivariate tests address whether or not the grouping variables (i.e., race, gender) included in each model have a statistically significant effect for all of the dependent variables (VFI functions), considered as a group. The statistics reported for the multivariate test include the Wilks' $\lambda$ value, the results of the $F$ test for significance, the relevant degrees of freedom, the $p$ value (significance), the partial $\eta^{2}$ (as an estimate of effect size), and the observed power. The tests of between-subjects effects shows the univariate ANOVA results for the grouping variables in the respective models on each of the outcome variables, considered individually. The statistics reported for the tests of between-subjects effects include the sum of squares (Type III), degrees of freedom, mean square, results of the $F$ test for significance, the $p$ value (significance), the partial $\eta^{2}$ (as an estimate of effect size), and the observed power.

Because our sample of students included those who were either currently enrolled in, or had previously enrolled in, service-learning courses, as well as those who had no prior experience with servicelearning, we ran a MANOVA model to test whether or not previous experience with service-learning was associated with differences in student responses to the VFI items in the survey. In our sample, 39 students indicated that they had previously taken a service-learning course and 91 did not. As shown in Table 2, there was no statistically significant difference that emerged in students' motivations based on whether or not the student had previously tak-

Table 2

MANOVA Findings: Prior Service-Learning Experience as the Grouping Variable

Multivariate Test

\begin{tabular}{lcccccc} 
& Wilks' $\lambda$ & $F$ & $d f$ & Sig. & Partial $\eta 2$ & Power \\
\hline $\begin{array}{l}\text { Prior ser- } \\
\text { vice-learning } \\
\text { experience }\end{array}$ & .976 & .508 & $(6,123)$ & .801 & .024 & .199 \\
\hline
\end{tabular}

Tests of Between-Subjects Effects

\begin{tabular}{|c|c|c|c|c|c|c|c|c|}
\hline & VFI Function & $\begin{array}{c}\text { Type III Sum } \\
\text { of Squares }\end{array}$ & $d f$ & Mean Square & $F$ & Sig. & Partial $\eta 2$ & $\begin{array}{c}\text { Observed } \\
\text { Power }\end{array}$ \\
\hline \multirow{6}{*}{$\begin{array}{l}\text { Prior ser- } \\
\text { vice-learning } \\
\text { experience }\end{array}$} & Protective function & .253 & 1 & .253 & .244 & .622 & .002 & .078 \\
\hline & Values function & .178 & 1 & .178 & .142 & .707 & .001 & .066 \\
\hline & Career function & .223 & 1 & .223 & .184 & .669 & .001 & .071 \\
\hline & Social function & .493 & 1 & .493 & .428 & .514 & .003 & .100 \\
\hline & Understanding function & .241 & 1 & .241 & .204 & .653 & .002 & .073 \\
\hline & Enhancement function & .361 & 1 & .361 & .324 & .570 & .003 & .087 \\
\hline \multirow[t]{6}{*}{ Error } & Protective function & 132.457 & 128 & 1.035 & & & & \\
\hline & Values function & 160.566 & 128 & 1.254 & & & & \\
\hline & Career function & 155.333 & 128 & 1.214 & & & & \\
\hline & Social function & 147.385 & 128 & 1.151 & & & & \\
\hline & Understanding function & 151.353 & 128 & 1.182 & & & & \\
\hline & Enhancement function & 142.528 & 128 & 1.113 & & & & \\
\hline \multirow[t]{6}{*}{ Total } & Protective function & 132.710 & 129 & & & & & \\
\hline & Values function & 160.743 & 129 & & & & & \\
\hline & Career function & 155.556 & 129 & & & & & \\
\hline & Social function & 147.878 & 129 & & & & & \\
\hline & Understanding function & 151.594 & 129 & & & & & \\
\hline & Enhancement function & 142.888 & 129 & & & & & \\
\hline
\end{tabular}


Table 3

Descriptive Statistics

\begin{tabular}{|c|c|c|c|c|c|}
\hline \multicolumn{2}{|l|}{ Grouping Variables } & & & \multirow[b]{8}{*}{ Std. Dev. } & \multirow[b]{8}{*}{$n$} \\
\hline Race & $\mathrm{n}$ & & & & \\
\hline White & 72 & & & & \\
\hline Minority & 58 & & & & \\
\hline \multicolumn{2}{|l|}{ Gender } & & & & \\
\hline Female & 104 & & & & \\
\hline Male & 26 & & & & \\
\hline VFI Functions & Race & Gender & Mean & & \\
\hline \multirow[t]{9}{*}{ Protective function } & \multirow[t]{3}{*}{ White } & Female & $-.1002(3.2264)$ & 1.03018 & 58 \\
\hline & & Male & $-.4205(2.9971)$ & .94573 & 14 \\
\hline & & Total & -.1625 (3.1789) & 1.01590 & 72 \\
\hline & \multirow[t]{3}{*}{ Minority } & Female & $.3241(3.4450)$ & 1.00163 & 46 \\
\hline & & Male & $-.2940(3.0750)$ & .76970 & 12 \\
\hline & & Total & $.1962(3.353)$ & .98498 & 58 \\
\hline & \multirow[t]{3}{*}{ Total } & Female & $.0875(3.3214)$ & 1.03464 & 104 \\
\hline & & Male & $-.3621(3.0348)$ & .85434 & 26 \\
\hline & & Total & $-.0024(3.2575)$ & 1.01428 & 130 \\
\hline \multirow[t]{9}{*}{ Values function } & \multirow[t]{3}{*}{ White } & Female & $-.0982(4.3031)$ & 1.09629 & 58 \\
\hline & & Male & $-.2633(4.2235)$ & 1.09966 & 14 \\
\hline & & Total & $-.1303(4.2866)$ & 1.09115 & 72 \\
\hline & \multirow[t]{3}{*}{ Minority } & Female & $.3205(4.4880)$ & .90902 & 46 \\
\hline & & Male & $-.9467(3.6313)$ & 1.43341 & 12 \\
\hline & & Total & $.0583(4.2803)$ & 1.14759 & 58 \\
\hline & \multirow[t]{3}{*}{ Total } & Female & $.0870(4.3835)$ & 1.03430 & 104 \\
\hline & & Male & $-.5787(3.9364)$ & 1.28590 & 26 \\
\hline & & Total & $-.0462(4.2838)$ & 1.11628 & 130 \\
\hline \multirow[t]{9}{*}{ Career function } & \multirow[t]{3}{*}{ White } & Female & $-.1255(3.8285)$ & 1.05014 & 58 \\
\hline & & Male & $-.4405(3.6824)$ & 1.01420 & 14 \\
\hline & & Total & $-.1867(3.7982)$ & 1.04376 & 72 \\
\hline & Minority & Female & $.4220(4.1560)$ & 1.00079 & 46 \\
\hline & & Male & $-.8420(3.3781)$ & 1.13039 & 12 \\
\hline & & Total & .1605 (3.9674) & 1.14196 & 58 \\
\hline & Total & Female & .1167 (3.9709) & 1.05949 & 104 \\
\hline & & Male & $-.6258(3.5348)$ & 1.06712 & 26 \\
\hline & & Total & $-.0318(3.8736)$ & 1.09812 & 130 \\
\hline Social function & White & Female & $-.0846(3.1138)$ & 1.05962 & 58 \\
\hline & & Male & $-.3879(3.1235)$ & 1.23936 & 14 \\
\hline & & Total & $-.1436(3.1159)$ & 1.09419 & 72 \\
\hline & Minority & Female & $.2506(3.3760)$ & 1.05495 & 46 \\
\hline & & Male & $-.1428(3.1219)$ & .86215 & 12 \\
\hline & & Total & $.1692(3.3144)$ & 1.02367 & 58 \\
\hline & Total & Female & $.0637(3.2278)$ & 1.06563 & 104 \\
\hline & & Male & $-.2748(3.1227)$ & 1.06832 & 26 \\
\hline & & Total & $-.0040(3.2044)$ & 1.07067 & 130 \\
\hline Understanding function & White & Female & $-.1442(4.1592)$ & 1.03927 & 58 \\
\hline & & Male & $-.3686(4.0235)$ & 1.01411 & 14 \\
\hline & & Total & $-.1879(4.1311)$ & 1.03122 & 72 \\
\hline & Minority & Female & $.3454(4.4120)$ & .95483 & 46 \\
\hline & & Male & $-.9136(3.7281)$ & 1.26453 & 12 \\
\hline & & Total & $.0849(4.2462)$ & 1.13711 & 58 \\
\hline & Total & Female & $.0723(4.2691)$ & 1.02749 & 104 \\
\hline & & Male & $-.6202(3.8803)$ & 1.14679 & 26 \\
\hline & & Total & $-.0662(4.1824)$ & 1.08404 & 130 \\
\hline Enhancement function & White & Female & $-.0886(3.7900)$ & 1.09431 & 58 \\
\hline & & Male & $-.5060(3.5735)$ & .90707 & 14 \\
\hline & & Total & $-.1698(3.7451)$ & 1.06757 & 72 \\
\hline & Minority & Female & $.2922(3.9700)$ & .97187 & 46 \\
\hline & & Male & $-.5293(3.5406)$ & .96784 & 12 \\
\hline & & Total & $.1222(3.8659)$ & 1.01937 & 58 \\
\hline & Total & Female & $.0798(3.8683)$ & 1.05427 & 104 \\
\hline & & Male & $-.5167(3.5576)$ & .91659 & 26 \\
\hline & & Total & $-.0395(3.7990)$ & 1.05245 & 130 \\
\hline
\end{tabular}

Note: The means shown above were derived after the factor analyses were run to reduce the variables to the six VFI functions. In parentheses, we have also included the Likert means to assist with interpretation. 
Table 4

MANOVA Findings: Race as the Grouping Variable

Multivariate Tests

\begin{tabular}{ccccccc} 
& & & & & \multicolumn{2}{c}{ Observed } \\
\hline Race & Wilks' $\lambda$ & $F$ & $d f$ & Sig. & Partial $\eta^{2}$ & Power \\
\hline
\end{tabular}

Tests of Between-Subjects Effects

\begin{tabular}{|c|c|c|c|c|c|c|c|c|}
\hline & $\begin{array}{c}\text { VFI } \\
\text { Function }\end{array}$ & $\begin{array}{l}\text { Type III Sum } \\
\text { of Squares }\end{array}$ & $d f$ & Mean Square & $F$ & Sig. & Partial $\eta^{2}$ & $\begin{array}{c}\text { Observed } \\
\text { Power }\end{array}$ \\
\hline \multirow[t]{6}{*}{ Race } & Protective function & 4.134 & 1 & 4.134 & 4.115 & $.045 * *$ & .031 & .521 \\
\hline & Values function & 1.143 & 1 & 1.143 & .917 & .340 & .007 & .158 \\
\hline & Career function & 3.873 & 1 & 3.873 & 3.269 & $.073 *$ & .025 & .434 \\
\hline & Social function & 3.143 & 1 & 3.143 & 2.780 & $.098 *$ & .021 & .380 \\
\hline & Understanding function & 2.390 & 1 & 2.390 & 2.050 & .155 & .016 & .295 \\
\hline & Enhancement function & 2.739 & 1 & 2.739 & 2.502 & .116 & .019 & .348 \\
\hline \multirow[t]{6}{*}{ Error } & Protective function & 128.576 & 128 & 1.005 & & & & \\
\hline & Values function & 159.600 & 128 & 1.247 & & & & \\
\hline & Career function & 151.682 & 128 & 1.185 & & & & \\
\hline & Social function & 144.735 & 128 & 1.131 & & & & \\
\hline & Understanding function & 149.204 & 128 & 1.166 & & & & \\
\hline & Enhancement function & 140.149 & 128 & 1.095 & & & & \\
\hline \multirow[t]{6}{*}{ Total } & Protective function & 132.710 & 129 & & & & & \\
\hline & Values function & 160.743 & 129 & & & & & \\
\hline & Career function & 155.556 & 129 & & & & & \\
\hline & Social function & 147.878 & 129 & & & & & \\
\hline & Understanding function & 151.594 & 129 & & & & & \\
\hline & Enhancement function & 142.888 & 129 & & & & & \\
\hline
\end{tabular}

Note: $* p<0.10, * * p<0.05, * * * p<0.01$

en a service-learning course. This was true for the complete MANOVA model as well as the individual univariate models for each outcome variable considered separately. Therefore, all student responses were combined for subsequent analyses.

Our final sample included 130 usable student responses. The descriptive statistics for the grouping variables and the VFI functions (after the factor analyses were conducted) are shown in Table 3 . We note that, for the descriptive statistics of the VFI functions, it is inappropriate to interpret negative values as necessarily implying negative impacts; rather, these values are useful for comparing between groups. Consistently throughout the findings, females reported greater levels than men on each of the VFI functions, and minority students reported greater levels than White students on each of the VFI functions. Whether or not these differences are statistically significant are indicated and described below and in Tables 4, 5, 6, and 7 .

In Table 4, we present the findings from the first of the four MANOVA models, which examines race as the single grouping variable. The results of the multivariate tests were not statistically significant, $F(6,123)=0.863, p=0.524$. When examined individually through the tests of between-subjects effects, race did have statistically significant effect on three of the VFI functions: protective, career, and social.

Table 5 shows the findings of the second MANOVA model, which examines gender as the single grouping variable. The results of the multivariate tests in this model were statistically significant, $F(6,123)=2.105, p=0.057$. When examined individually through the between-subjects effects, gender had a statistically significant effect on five of the six VFI functions, social being the lone exception.

In Table 6, we present the findings of the third MANOVA model, in which we examined both race and gender as grouping variables. In the multivariate tests, race again is not statistically significant, $F(6,122)=0.945, p=0.466$, and gender remains statistically significant, $F(6,122)=2.182, p=0.049$. When examined individually through the betweensubjects effects, race has a statistically significant effect on four of the six VFI functions (protective, career, social, and enhancement), and gender again has a statistically significant effect on five of the six VFI functions, with social again being the lone exception.

The findings of the fourth and final MANOVA 
Table 5

MANOVA Findings: Gender and the Grouping Variable

Multivariate Tests

\begin{tabular}{ccccccc}
\hline & & & \multicolumn{3}{c}{ Observed } \\
& Wilks' $\lambda$ & $F$ & $d f$ & Sig. & \multicolumn{3}{c}{ Partial $\eta^{2}$} & Power \\
\hline Gender & .907 & 2.105 & $(6,123)$ & $.057 *$ & .093 & .738 \\
\hline
\end{tabular}

Tests of Between-Subjects Effects

\begin{tabular}{|c|c|c|c|c|c|c|c|c|}
\hline & VFI Function & $\begin{array}{l}\text { Type III Sum } \\
\text { of Squares }\end{array}$ & $d f$ & $\begin{array}{l}\text { Mean } \\
\text { Square }\end{array}$ & $F$ & Sig. & Partial $\eta^{2}$ & $\begin{array}{c}\text { Observed } \\
\text { Power }\end{array}$ \\
\hline \multirow[t]{6}{*}{ Gender } & Protective function & 4.204 & 1 & 4.204 & 4.188 & $.043 * *$ & .032 & .528 \\
\hline & Values function & 9.217 & 1 & 9.217 & 7.786 & $.006 * * *$ & .057 & .791 \\
\hline & Career function & 11.467 & 1 & 11.467 & 10.187 & $.002 * * *$ & .074 & .886 \\
\hline & Social function & 2.382 & 1 & 2.382 & 2.096 & .150 & .016 & .301 \\
\hline & Understanding function & 9.974 & 1 & 9.974 & 9.015 & $.003 * * *$ & .066 & .846 \\
\hline & Enhancement function & 7.402 & 1 & 7.402 & 6.993 & $.009 * * *$ & .052 & .747 \\
\hline \multirow[t]{6}{*}{ Error } & Protective function & 128.506 & 128 & 1.004 & & & & \\
\hline & Values function & 151.526 & 128 & 1.184 & & & & \\
\hline & Career function & 144.089 & 128 & 1.126 & & & & \\
\hline & Social function & 145.496 & 128 & 1.137 & & & & \\
\hline & Understanding function & 141.620 & 128 & 1.106 & & & & \\
\hline & Enhancement function & 135.486 & 128 & 1.058 & & & & \\
\hline \multirow{6}{*}{ Total } & Protective function & 132.710 & 129 & & & & & \\
\hline & Values function & 160.743 & 129 & & & & & \\
\hline & Career function & 155.556 & 129 & & & & & \\
\hline & Social function & 147.878 & 129 & & & & & \\
\hline & Understanding function & 151.594 & 129 & & & & & \\
\hline & Enhancement function & 142.888 & 129 & & & & & \\
\hline
\end{tabular}

Note: $* p<0.10, * * p<0.05, * * * p<0.01$

model are presented in Table 7. In this model, we examined race and gender as grouping variables as well as the interaction of those terms. In the multivariate tests, race was not statistically significant, $F(6,121)=0.567, p=0.756$, and the interaction of race and gender was also not statistically significant, $F(6,121)=1.337, p=0.246$. As in the second and third models, gender was again statistically significant, $F(6,121)=2.512, p=0.025$. When examined individually through the between-subjects effects, race no longer had a statistically significant effect on any of the six VFI functions; gender continued to have a statistically significant effect on five the six VFI functions (with social again being the lone exception); and interaction term had a statistically significant effect on the values, career, and understanding functions.

To summarize, when considering the ANOVA models and findings from the multivariate tests, only gender had a statistically significant effect on the outcome variables in the three models in which it was included as a grouping variable. It is important to note that the effect sizes (partial $\eta^{2}$ ) for gender are fairly small in the second, third and fourth models $(0.093,0.097$, and 0.111 , respectively).

Although gender was the only grouping variable with a statistically significant effect in the multivariate tests, it is also worth summarizing the results of the between-subjects effects for the individual VFI functions. For the protective function, race is statistically significant in the first model, in which race is the single grouping variable, and remains statistically significant in the third model, which examines both race and gender as grouping variables. However, in the final model, which adds the interaction term, race is no longer statistically significant. In all three models in which it was examined as a grouping variable, gender was statistically significant. In the final model, the interaction term is not statistically significant.

For the values function, race does not have a statistically significant effect in any of the three models in which it is included; however, gender does have a statistically significant effect for all three models in which it is included. Finally, the interaction term between race and gender also has a statistically significant effect in the final model.

For the career function, race has a statistically significant effect in the model in which it is the sole grouping variables and remains statistically significant when gender is also examined. However, when the interaction term is included in the final model, 
Table 6

MANOVA Findings: Race and Gender as Grouping Variables

Multivariate Tests

\begin{tabular}{lllllll} 
& & \multicolumn{2}{c}{ Wilks' $\lambda$} & & \multicolumn{2}{c}{ Observed } \\
\hline Race & .956 & & $d f$ & Sig. & Partial $\eta^{2}$ Power \\
Gender & .903 & .945 & $(6,122)$ & .466 & .044 & .362 \\
\hline
\end{tabular}

Tests of Between-Subjects Effects

\begin{tabular}{|c|c|c|c|c|c|c|c|c|}
\hline & VFI Function & $\begin{array}{c}\text { Type III Sum } \\
\text { of Squares }\end{array}$ & $d f$ & Mean Square & $F$ & Sig. & Partial $\eta^{2}$ & $\begin{array}{c}\text { Observed } \\
\text { Power }\end{array}$ \\
\hline \multirow[t]{6}{*}{ Race } & Protective function & 4.265 & 1 & 4.265 & 4.360 & $.039 * *$ & .033 & .545 \\
\hline & Values function & 1.246 & 1 & 1.246 & 1.053 & .307 & .008 & .175 \\
\hline & Career function & 4.083 & 1 & 4.083 & 3.704 & $.057 *$ & .028 & .480 \\
\hline & Social function & 3.229 & 1 & 3.229 & 2.883 & $.092 *$ & .022 & .392 \\
\hline & Understanding function & 2.544 & 1 & 2.544 & 2.323 & .130 & .018 & .328 \\
\hline & Enhancement function & 2.881 & 1 & 2.881 & 2.759 & $.099 *$ & .021 & .378 \\
\hline \multirow[t]{6}{*}{ Gender } & Protective function & 4.335 & 1 & 4.335 & 4.431 & $.037 * *$ & .034 & .551 \\
\hline & Values function & 9.320 & 1 & 9.320 & 7.876 & $.006 * * *$ & .058 & .795 \\
\hline & Career function & 11.677 & 1 & 11.677 & 10.592 & $.001 * * *$ & .077 & .898 \\
\hline & Social function & 2.468 & 1 & 2.468 & 2.203 & .140 & .017 & .314 \\
\hline & Understanding function & 10.128 & 1 & 10.128 & 9.249 & $.003 * * *$ & .068 & .855 \\
\hline & Enhancement function & 7.544 & 1 & 7.544 & 7.225 & $.008 * * *$ & .054 & .760 \\
\hline \multirow[t]{6}{*}{ Error } & Protective function & 124.241 & 127 & .978 & & & & \\
\hline & Values function & 150.280 & 127 & 1.183 & & & & \\
\hline & Career function & 140.005 & 127 & 1.102 & & & & \\
\hline & Social function & 142.267 & 127 & 1.120 & & & & \\
\hline & Understanding function & 139.076 & 127 & 1.095 & & & & \\
\hline & Enhancement function & 132.605 & 127 & 1.044 & & & & \\
\hline \multirow[t]{6}{*}{ Total } & Protective function & 132.710 & 129 & & & & & \\
\hline & Values function & 160.743 & 129 & & & & & \\
\hline & Career function & 155.556 & 129 & & & & & \\
\hline & Social function & 147.878 & 129 & & & & & \\
\hline & Understanding function & 151.594 & 129 & & & & & \\
\hline & Enhancement function & 142.888 & 129 & & & & & \\
\hline
\end{tabular}

Note: $* p<0.10, * * p<0.05, * * * p<0.01$

race is no longer statistically significant. Gender as a grouping variable has a statistically significant in all three models in which it is examined. Finally, the interaction term has a statistically significant effect on the career function.

For the social function, race is statistically significant when it is examined as the single grouping variable and remains statistically significant when gender is added in the third model. However, in the final model in which the interaction term is added as a grouping variable, race is no longer statistically significant. Gender does not have a statistically significant effect in any of the models, and the interaction term also does not have a statistically significant effect on the social function.

For the understanding function, race as a grouping variable does not have a statistically significant effect in any of the models in which it is included. Gender, on the other hand, is statistically significant in all three of the models in which it is includ- ed. Finally, the interaction term is also statistically significant in the final model when it is included.

Finally, for the enhancement function, race is statistically significant only in the third model, when race and gender are both examined as grouping variables; it is not statistically significant in first or final models. Gender as a grouping variable is statistically significant in all three models in which it is included, and the interaction term is not statistically significant when it is added in the final model.

Overall, when race is examined alone as a grouping variable, it has a statistically significant effect on the protective, career, and social functions; the enhancement function is also statistically significant in the third model. In the final model, race is not statistically significant for any of the VFI functions. Gender, on the other hand, has a statistically significant effect for five of the VFI functions (the social function being the exception) in all three models in which it is included. Finally, the interac- 
Table 7

MANOVA Findings: Race, Gender, and their Interaction as Grouping Variables

Multivariate Tests

\begin{tabular}{lcccccc} 
& Wilks' $\lambda$ & $F$ & $d f$ & Sig. & Partial $\eta^{2}$ & $\begin{array}{c}\text { Observed } \\
\text { Power }\end{array}$ \\
\hline Race & .973 & .567 & $(6,121)$ & .756 & .027 & .220 \\
Gender & .889 & 2.512 & $(6,121)$ & $.025^{* *}$ & .111 & .823 \\
Race * & .938 & 1.337 & $(6,121)$ & .246 & .062 & .507 \\
Gender & & & & & & \\
\hline
\end{tabular}

Tests of Between-Subjects Effects

\begin{tabular}{|c|c|c|c|c|c|c|c|c|}
\hline & VFI Function & $\begin{array}{l}\text { Type III Sum } \\
\text { of Squares }\end{array}$ & $d f$ & $\begin{array}{l}\text { Mean } \\
\text { Square }\end{array}$ & $F$ & Sig. & Partial $\eta^{2}$ & $\begin{array}{c}\text { Observed } \\
\text { Power }\end{array}$ \\
\hline \multirow[t]{6}{*}{ Race } & Protective function & 1.566 & 1 & 1.566 & 1.594 & .209 & .012 & .240 \\
\hline & Values function & .362 & 1 & .362 & .316 & .575 & .003 & .086 \\
\hline & Career function & .110 & 1 & .110 & .103 & .749 & .001 & .062 \\
\hline & Social function & 1.738 & 1 & 1.738 & 1.540 & .217 & .012 & .234 \\
\hline & Understanding function & .016 & 1 & .016 & .015 & .903 & .000 & .052 \\
\hline & Enhancement function & .660 & 1 & .660 & .631 & .428 & .005 & .124 \\
\hline \multirow[t]{6}{*}{ Gender } & Protective function & 4.545 & 1 & 4.545 & 4.626 & $.033 * *$ & .035 & .569 \\
\hline & Values function & 10.588 & 1 & 10.588 & 9.264 & $.003 * * *$ & .068 & .856 \\
\hline & Career function & 12.869 & 1 & 12.869 & 11.980 & $.001 * * *$ & .087 & .930 \\
\hline & Social function & 2.505 & 1 & 2.505 & 2.219 & .139 & .017 & .315 \\
\hline & Understanding function & 11.357 & 1 & 11.357 & 10.715 & $.001 * * *$ & .078 & .901 \\
\hline & Enhancement function & 7.921 & 1 & 7.921 & 7.575 & $.007 * * *$ & .057 & .780 \\
\hline \multirow{6}{*}{$\begin{array}{l}\text { Race * } \\
\text { Gender }\end{array}$} & Protective function & .458 & 1 & .458 & .466 & .496 & .004 & .104 \\
\hline & Values function & 6.268 & 1 & 6.268 & 5.484 & $.021 * *$ & .042 & .642 \\
\hline & Career function & 4.648 & 1 & 4.648 & 4.327 & $.040 * *$ & .033 & .542 \\
\hline & Social function & .042 & 1 & .042 & .037 & .848 & .000 & .054 \\
\hline & Understanding function & 5.526 & 1 & 5.526 & 5.213 & $.024 * *$ & .040 & .620 \\
\hline & Enhancement function & .843 & 1 & .843 & .806 & .371 & .006 & .145 \\
\hline \multirow[t]{6}{*}{ Error } & Protective function & 123.783 & 126 & .982 & & & & \\
\hline & Values function & 144.012 & 126 & 1.143 & & & & \\
\hline & Career function & 135.357 & 126 & 1.074 & & & & \\
\hline & Social function & 142.225 & 126 & 1.129 & & & & \\
\hline & Understanding function & 133.550 & 126 & 1.060 & & & & \\
\hline & Enhancement function & 131.763 & 126 & 1.046 & & & & \\
\hline \multirow{6}{*}{ Total } & Protective function & 132.710 & 129 & & & & & \\
\hline & Values function & 160.743 & 129 & & & & & \\
\hline & Career function & 155.556 & 129 & & & & & \\
\hline & Social function & 147.878 & 129 & & & & & \\
\hline & Understanding function & 151.594 & 129 & & & & & \\
\hline & Enhancement function & 142.888 & 129 & & & & & \\
\hline
\end{tabular}

Note: $* p<0.10, * * p<0.05, * * * p<0.01$

tion of gender and race has a statistically significant effect in the final model (the only model in which it is included) for three of the VFI functions: values, career, and understanding.

\section{Discussion}

While acknowledging the exploratory nature of this study and its inherent generalizability limitations, we believe that the findings emphasize our primary contention - students are motivated to participate in service-learning for a variety of reasons based on their backgrounds and experiences. In general, it appears that a student's race can affect her or his individual motivational functions related to service-learning courses, and when there is a significant difference, minority students report greater levels of motivation than White students. The minority students motivated by enhancement function may be expecting service-learning to empower them with feelings of self-efficacy that come from the responsibility and autonomy that often are associated with service-learning courses.

Related to students' egos, minority students also may be more motivated by the protective function because they feel guilt for being more fortunate 
than others from their racial group, or may be using service-learning to protect themselves from feelings of isolation or other stresses. Assuaging feelings of isolation may also contribute to students motivated by the social function, as well as the perceived expectation that they should give back to their communities. Finally, minority students may be motivated by the career function because they feel that service-learning can provide them with the skills necessary to secure employment in their chosen fields. These findings align with the student responses reported in Pearl and Christensen (2016) that indicate minority students may lack intrinsic advantages (such as high levels of social capital) and subsequently enroll in service-learning courses to make up for these potential deficits.

However, a student's race does not appear to be nearly as impactful as the student's gender, even to the degree that when gender is examined in the MANOVA models in conjunction with race the statistically significant effect of race diminishes or disappears completely. With the exception of the social function, women report greater levels of motivations for five of the six VFI functions. Regarding the values function, female students may be motivated to participate in service-learning because it provides them with an outlet to develop and express their attitudes and values related to social responsibility (Clary et al., 1998; Stukas et al., 1999). Similar to minority students, female students appear to see service-learning as an opportunity to both enhance and protect their egos, allowing them to be more engaged in their courses and in their college experience in general, which can lead to increased feelings of responsibility and self-efficacy. This, in turn, may account for female students' motivations related to the career and understanding functions, such that they gain valuable and marketable skills in addition to the confidence to utilize those skills - important qualities due to the fact that women face many of the same intrinsic disadvantages as minority students.

Finally, it is important to note that while the multivariate effects were not statistically significant for the interaction term in the last model, the values, career, and understanding functions were all statistically significant when examined individually. While exploratory in nature, these findings are indicative of the inherent complexity of students' identities, consistent with Jones and McEwen's (2000) model of multiple dimensions of identity (see also, Abes, Jones, \& McEwen, 2007; Jones, 2009). As students navigate their multiple forms of identity, such as race and gender, and balance those identities within the contextual influences within which they operate, they are in a continually shifting state of their different identities playing a role in their actions at any given time. Especially at a time when students are learning more about themselves, they are working to sort out how to balance their dominant and non-dominant identities. They ways in which these identities intersect has been shown to influence student motivation for community service involvement (Jones \& Hill, 2003).

So what do these findings tell us? First, it may indicate that both minority and female students are differently motivated than their White and male counterparts, which may, in part, help explain some of the results of previous work indicating differing outcomes for students based on their backgrounds (Chesler \& Vasques Scalera, 2000; Coles, 1999; Green, 2001; Mitchell \& Donahue, 2009). Our findings build on these previous studies by providing a more nuanced understanding of what motivates students to achieve positive learning, personal, and social outcomes.

The findings from the current study support other scholarship (Pearl \& Christensen, 2016) that suggest that students from different backgrounds may have different motivations for enrolling in servicelearning courses. Students may seek to satisfy different needs and have different expectations in terms of anticipated outcomes. As service-learning instructors and administers, we can point to myriad examples of how participating in a service-learning experience can positively affect students, and as a field, we have spent a great amount of time and energy to better understand these student outcomes (as well as the outcomes for communities, faculty members, and institutions). However, we have paid less attention to inputs such as student traits and motivations. Previous research has suggested that how instructors frame reflection strategies can influence students' outcomes (Einfeld \& Collins, 2008). If instructors have a clearer idea of what motivates different types of students, they can frame recruitment and reflection activities to better help students achieve their goals.

Further, it is important for service-learning instructors to consider their own identities and perspectives when framing these reflection strategies and resist the temptation or natural proclivity to frame reflections based on their own identities and lenses. Instructors need to be purposeful in ensuring that reflection strategies and the prompts they provide speak to all students and their identities. For example, minority students may be uncomfortable when engaging in conversations about race with their White classmates (Seider, Huguley, \& Novick, 2013). Further, because a large number of service-learning projects are involved with minori- 
ty communities, what message does this send to students from these minority communities?

Given the differences that emerged in the findings between the motivations of male and female students, it is also important to consider how service-learning is viewed (and rewarded) structurally by the institutions. If service and teaching have traditionally been viewed as "women's work" (Park, 1996), we may be sending a problematic message to students that service-learning is less rigorous and prestigious. We believe our findings support existing calls to further explore viewing community engagement through a feminist lens (Iverson \& James, 2014).

As with any empirical study, there are certain limitations to our work. For example, our work is based on a relatively small sub-set of students from one (albeit large, public) institution. It would be imprudent to generalize these findings to all students. Further, we acknowledge that our consideration of the race of students as either White or minority is an oversimplification of race and how students identify with this complex trait. We also acknowledge the limitations of self-reported data and possibilities of mono-method bias.

Despite these issues, we believe that this exploratory work sets the foundation for continued research with more robust samples of students. The results of this study raise several questions that can be addressed through continued inquiry. For example, how do students' motivations and other inputs affect their learning outcomes? And, how do individual students' personal narratives influence their motivation for engaged learning? The current study only examines the student inputs for servicelearning. Ultimately, we believe that building a comprehensive dataset inclusive of students' motivations, detailed experiences in service-learning courses, and a wide range of learning outcomes will continue to help us understand how participating in service-learning affects students.

Future research should also include in-depth qualitative analysis. When examined in concert with the findings of Pearl and Christensen (2016), the current study suggests that there may be motivational differences among students but only hypothesizes as to why these differences exist. In particular, we believe one methodological approach that may be highly instructive is narrative inquiry (Connelly \& Clandinin, 1990). This approach allows for in-depth exploration of students' identities, how they developed those identities, and provides a more nuanced approach to the racial and ethnic perspectives of individuals rather than the simplistic categorization of White or minority. Further, this would open the door for the exploration of individual identities not included in this study.

From the perspective of research and advancing our knowledge of service-learning in higher education, this study establishes a foundation that better accounts for students" "inputs" in order to better understand various service-learning outcomes. We also propose that administrators and servicelearning instructors consider our findings from the perspective of how service-learning courses are delivered. Research has suggested that instructors are able to emphasize student outcomes based on the reflection prompts they give to students (Einfeld \& Collins, 2008). Therefore, if students are motivated to achieve different outcomes and enroll in service-learning for different purposes, it is useful for instructors to understand these motivations when constructing their course syllabi and reflection strategies.

Finally, to close the gap between minority student interest and actual enrollment in servicelearning courses, administrators should strategize how to communicate the ways that enrolling in service-learning can help students satisfy their motivations and achieve their higher education goals. Clary et al. (1998) stress the importance of persuasive messaging when it comes to appealing to individuals' motivations to volunteer; a similar approach should be taken to match the messaging of service-learning's potential positive impacts to the various motivations of students. This is particularly important given that Clary et al. also found that when the motivations of volunteers and the situational fits of their service roles are aligned, they are likely to continue to serve in the future. This lesson should be considered for students enrolled in service-learning courses.

If we are not purposeful in how we speak to the various motivations of our students, and some of those students do not have positive experiences with service-learning, are we essentially telling some of them that their active participation in society through service is not important? If a goal of service-learning is to develop future engaged citizen-leaders, we must make sure that we provide engaging service-learning experiences with all of our students in mind. Therefore, it is important to continue to unpack students' complex motives for participating in service-learning.

\section{References}

Abes, E. S., Jones, S. R., \& McEwen, M. K. (2007). Reconceptualizing the model of multiple dimensions of identity: The role of meaning-making capacity in the construction of multiple identities. Journal of College Student Development, 48(1), 1-22. 
Allison, L. D., Okun, M. A., \& Dutridge, K. S. (2002). Assessing volunteer motives: A comparison of an openended probe and Likert rating scales. Journal of Community \& Applied Social Psychology, 12(4), 243-255.

Astin, A. W. (2012). Assessment for excellence: The philosophy and practice of assessment and evaluation in higher education. Lanham, MD: Rowman \& Littlefield Publishers.

Battistoni, R.M. (2012). Civic learning through service learning. In P. H. Clayton, R. G. Bringle, \& J. A. Hatcher (Eds.), Research on service-learning: Conceptual frameworks and assessment: Volume 2A: Students and faculty (pp. 111-132). Sterling, VA: Stylus.

Brandenberger, J.W. (2012). Investigating personal development outcomes in service learning. In P. H. Clayton, R. G. Bringle, \& J. A. Hatcher (Eds.), Research on service-learning: Conceptual frameworks and assessment: Volume 2A: Students and faculty (pp. 133-156). Sterling, VA: Stylus.

Brayley, N., Obst, P., White, K. M., Lewis, I. M., Warburton, J., \& Spencer, N. M. (2014). Exploring the validity and predictive power of an extended volunteer functions inventory within the context of episodic skilled volunteering by retirees. Journal of Community Psychology, 42(1), 1-18.

Bringle, R. G., Phillips, M. A., \& Hudson, M. (2004). The measure of service learning: Research scales to assess student experiences. Washington, DC: American Psychological Association.

Brown, E., \& Lankford, H. (1992). Gifts of money and gifts of time: Estimating the effects of tax prices and available time. Journal of Public Economics, 47(3), 321-341.

Bryant, W. K., Jeon-Slaughter, H., Kang, H., \& Tax, A. (2003). Participation in philanthropic activities: Donating money and time. Journal of Consumer Policy, 26(1), 42-73.

Butin, D. W. (2006). The limits of service-learning in higher education. The Review of Higher Education, 29(4), 473-498. doi:10.1353/rhe.2006.0025

Chesler, M., \& Scalera, C. V. (2000). Race and gender issues related to service-learning research. Michigan Journal of Community Service Learning, Special Issue, 18-27.

Christensen, R. K., Stritch, J. M., Kellough, J. E., \& Brewer, G. A. (2015). Identifying student traits and motives to service-learn: Public service orientation among new college freshmen. Journal of Higher Education Outreach and Engagement, 19(4), 39-62. Retrieved from http://openjournals.libs.uga.edu/index. $\mathrm{php} / \mathrm{jheoe} / \mathrm{article} / \mathrm{view} / 1530$

Clary, E. G., Snyder, M., Ridge, R. D., Copeland, J., Stukas, A. A., Haugen, J. et al. (1998). Understanding and assessing the motivations of volunteers: A functional approach. Journal of Personality and Social Psychology, 74(6), 1516-1530. Retrieved from http://www.ncbi. nlm.nih.gov/pubmed/9654757

Clayton, P. H., Bringle, R. G., \& Hatcher, J. A. (Eds.). (2012). Research on service-learning: Conceptual frameworks and assessment: Volume 2A: Students and faculty. Sterling, VA: Stylus.
Coles, R. (1999). Race-focused service-learning courses: Issues and recommendations. Michigan Journal of Community Service Learning, 6, 97-105.

Connelly, F. M., \& Clandinin, D. J. (1990). Stories of experience and narrative inquiry. Educational Researcher, 19(5), 2-14.

Deardorff, D.K, \& Edwards, K.E. (2012). Framing and assessing students' intercultural competence in service learning. In P. H. Clayton, R. G. Bringle, \& J. A. Hatcher (Eds.), Research on service-learning: Conceptual frameworks and assessment: Volume 2A: Students and faculty (pp. 157-183). Sterling, VA: Stylus.

Einfeld, A., \& Collins, D. (2008). The relationships between service-learning, social justice, multicultural competence, and civic engagement. Journal of College Student Development, 49(2), 95-109. Retrieved from http://search.proquest.com/docview/195183025?accountid $=159965$

Einolf, C. (2011). Gender differences in the correlates of volunteering and charitable giving. Nonprofit and Voluntary Sector Quarterly, 40(6), 1092-1112. doi:10.1177/ 0899764010385949

Eyler, J., Giles, D., \& Gray, C. (1999). At a glance: What we know about the effects of service-learning on students, faculty, institutions, and communities, 1993 1999. Nashville, TN: Vanderbilt University.

Finkelstein, M. A. (2008). Volunteer satisfaction and volunteer action: A functional approach. Social Behavior and Personality: An International Journal, 36(1), 918.

Fitch, P., Steinke, P., \& Hudson, T.D. (2012). Research and theoretical perspectives on cognitive outcomes of service learning. In P. H. Clayton, R. G. Bringle, \& J. A. Hatcher (Eds.), Research on service-learning: Conceptual frameworks and assessment: Volume 2A: Students and faculty (pp. 57-84). Sterling, VA: Stylus.

Fletcher, T. D., \& Major, D. A. (2004). Medical students' motivations to volunteer: An examination of the nature of gender differences. Sex Roles, 51(1-2), 109-114.

Green, A. E. (2001). "But you aren't White": Racial perceptions and service-learning. Michigan Journal of Community Service Learning, 8(1), 18-26.

Hogg, M. A., \& Terry, D. I. (2000). Social identity and self-categorization processes in organizational contexts. Academy of Management Review, 25(1), 121140.

Huberty, C. J. \& Petoskey, M. D. (2000). Multivariate analysis of variance and covariance. In H. E. Tinsley \& S. D. Brown (Eds.), Handbook of applied multivariate statistics and mathematical modeling. San Diego, CA: Academic Press.

Iverson, S. V. \& James, J. H. (2014). Feminism and community engagement: An overview. In S. V. Iverson \& J. H. James (Eds.), Feminist community engagement: Achieving praxis (pp. 9-27). New York: Palgrave MacMillan.

Jacoby, B. (2015). Service-learning essentials: Questions, answers, and lessons learned. San Francisco: Jossey-Bass.

Jameson, J.K., Clayton, P.H., \& Ash S.L. (2012). Con- 
ceptualizing, assessing, and investigating academic learning in service learning. In P. H. Clayton, R. G. Bringle, \& J. A. Hatcher (Eds.), Research on servicelearning: Conceptual frameworks and assessment: Volume 2A: Students and faculty (pp. 85-110). Sterling, VA: Stylus.

Jones, S. R. (2009). Constructing identities at the intersections: An autoethnographic exploration of multiple dimensions of identity. Journal of College Student Development, 50(3), 287-304.

Jones, S. R., \& Hill, K. E. (2003). Understanding patterns of commitment: Student motivation for community service involvement. The Journal of Higher Education, 74(5), 516-539.

Jones, S. R., \& McEwen, M. K. (2000). A conceptual model of multiple dimensions of identity. Journal of College Student Development, 41(4), 405-414.

Katz, D. (1960). The functional approach to the study of attitudes. Public Opinion Quarterly, 24(2), 163-204.

Lai, M. H., Ren, M. Y., Wu, A., \& Hung, E. P. (2013). Motivation as mediator between national identity and intention to volunteer. Journal of Community \& Applied Social Psychology, 23(2), 128-142.

Laurence, J. (2009). The effect of ethnic diversity and community disadvantage on social cohesion: A multilevel analysis of social capital and interethnic relations in UK communities. European Sociological Review. Advance online publication. doi:10.1093/esr/jcp057

Matthews, P., Pearl, A., \& Wilder, S., (2014, October). Characteristics of effective practice by faculty in service-learning courses. Poster presented at the Annual Conference of the Engagement Scholarship Consortium, Edmonton, AB, Canada.

Manud, P. (2014). Understanding what motivates participation in environmental digital citizen science across different sectors of society in the United Kingdom. Unpublished master's thesis, Imperial College, London, England. Retrieved from http://www.iccs.org.uk/ wp-content/uploads/2011/10/Maund_Phoebe_ConSci_2014.pdf

Mesch, D. J., Rooney, P. M., Steinberg, K. S., \& Denton, B. (2006). The effects of race, gender, and marital status on giving and volunteering in Indiana. Nonprofit and Voluntary Sector Quarterly, 35(4), 565-587.

Mitchell, T. D., \& Donahue, D. M. (2009). "I do more service in this class than I ever do at my site": Paying attention to the reflections of students of color in service-learning. In J. Strait \& M. Lima (Eds.), The future of service-learning: New solutions for sustaining and improving practice (pp. 172-190). Sterling, VA: Stylus Publishing.

Moely, B. E., \& Ilustre, V. (2014). The impact of servicelearning course characteristics on university students' learning outcomes. Michigan Journal of Community Service Learning, 21(1), 5-17.

Musick, M., \& Wilson, J. (2008). Volunteers: A social profile. Bloomington, IN: Indiana University Press

Musick, M. A., Wilson, J., \& Bynum, W. E. (2000). Race and formal volunteering: The differential effects of call and religion. Social Forces, 78(4), 1539-1571.
Okun, M. A., Barr, A., \& Herzog, A. (1998). Motivation to volunteer by older adults: A test of competing measurement models. Psychology and Aging, 13(4), 608621.

Okun, M. A., \& Schultz, A. (2003). Age and motives for volunteering: Testing hypotheses derived from socioemotional selectivity theory. Psychology and Aging, 18(2), 231-239.

Olney, C., \& Grande, S. (1995). Validation of a scale to measure development of social responsibility. Michigan Journal of Community Service Learning, 2, 43-53.

Park, S. M. (1996). Research, teaching, and service: Why shouldn't women's work count? The Journal of Higher Education, 67(1), 46-84.

Pearl A. \& Christensen, R. K. (2016, October). First-year student motivations for service-learning: Exploring minority student perceptions. Paper presented at the Annual Conference of the Engagement Scholarship Consortium, Omaha, NE.

Rotolo, T., \& Wilson, J. (2011). State-level differences in volunteering in the United States. Nonprofit and Voluntary Sector Quarterly. Advance online publication. doi: $10.1177 / 0899764011412383$

Schatteman, A. M. (2014). Academics meets action: Community engagement motivations, benefits, and constraints. Journal of Community Engagement and Higher Education, 6(1), 17-30.

Seider, S., Huguley, J. P., \& Novick, S. (2013). College students, diversity, and community service learning. Teachers College Record, 115(3), 1-44.

Smith, M. T. (2002, November). The decision to volunteer: Do childhood human capital investments impact the valuation of time? Paper presented at the ARNOVA Annual Conference, Montreal, Canada.

Smith, M., Bruner, J., \& White, R. (1956). Opinions and personality. New York: Wiley.

Stukas, A.A., Clary, E.G., \& Snyder, M. (1999). Servicelearning: Who benefits and why. Social Policy Report: Society for Research in Child Development, 13(4), 119.

Tavakol, M., \& Dennick, R. (2011). Making sense of Cronbach's alpha. International Journal of Medical Education, 2, 53-55.

Terrell, F., Moseley, K. L., Mosley, K. L., Terrell, A. S., \& Nickerson, K. J. (2004). The relationship between motivation to volunteer, gender, cultural mistrust, and willingness to donate organs among Blacks. Journal of the National Medical Association, 96(1), 53-60.

Van Slyke, D. M., Ashley, S., \& Johnson, J. L. (2007). Nonprofit performance, fund-raising effectiveness, and strategies for engaging African Americans in philanthropy. The American Review of Public Administration, 37(3), 278-305.

Van Slyke, D. M., \& Eschholz, S. (2002, November). Are women more generous than men? Gender differences in motivations for charitable giving. Paper presented at the ARNOVA Annual Conference, Montreal, Canada.

Wilson, J. \& Musick, M. (1997). Who cares? Toward an integrated theory of volunteer work. American Sociological Review, 65(5), 694-713. 
Authors

ANDREW J. PEARL (andrew.pearl@ung.edu) serves as the University of North Georgia's first director of academic engagement, where his responsibilities include faculty development, building mutually-beneficial community-university partnerships, and fostering an institutional culture supportive of community engagement. His scholarship focuses on faculty member motivations related to the scholarship of engagement, student motivations and outcomes related to service-learning experiences, and institutional and public policies that affect community engagement in higher education. He received his Ph.D. from the University of Georgia's Institute of Higher Education.
ROBERT K. CHRISTENSEN (rkc@byu.edu) is an associate professor in Brigham Young University's Romney Institute of Public Management. He received his Ph.D. from Indiana University. His research interests include public service career attraction and socialization in higher education. $\mathrm{He}$ is a research fellow at Arizona State University's Center for Organization Research \& Design and a co-researcher at Seoul National University's Center for Government Competitiveness. He is a faculty advisor at Brigham Young University's Grantwell, a student-run, faculty-advised philanthropic consulting and service-learning program. 
Appendix A

\begin{tabular}{|c|c|c|c|c|c|}
\hline \multirow[t]{2}{*}{ Function } & \multirow[t]{2}{*}{ Item } & \multicolumn{2}{|c|}{$\begin{array}{l}\text { Current or previous } \\
\text { SL experience }\end{array}$} & \multicolumn{2}{|c|}{$\begin{array}{l}\text { No prior SL } \\
\text { experience }\end{array}$} \\
\hline & & Mean & Std. Dev. & Mean & Std. Dev. \\
\hline \multirow[t]{5}{*}{$\begin{array}{l}\text { Protective } \\
\text { function }\end{array}$} & $\begin{array}{l}\text { No matter how bad I've been feeling, my (a) ser- } \\
\text { vice-learning course can (would) help me to forget } \\
\text { about it }\end{array}$ & 3.51 & 1.089 & 3.13 & .995 \\
\hline & $\begin{array}{l}\text { My (a) service-learning course (would) make(s) me feel } \\
\text { less lonely }\end{array}$ & 3.17 & 1.069 & 3.14 & 1.023 \\
\hline & $\begin{array}{l}\text { Participating in service-learning (would) relieve(s) me } \\
\text { of some of the guilt over being more fortunate than } \\
\text { others }\end{array}$ & 3.08 & 1.193 & 3.16 & 1.106 \\
\hline & $\begin{array}{l}\text { My experience with service-learning (would) help(s) me } \\
\text { work through my own personal problems }\end{array}$ & 3.24 & 1.208 & 3.36 & 1.009 \\
\hline & $\begin{array}{l}\text { My (a) service-learning course can (would) provide me } \\
\text { with a good escape from my own troubles }\end{array}$ & 3.24 & 1.088 & 3.38 & 1.048 \\
\hline \multirow[t]{5}{*}{ Values function } & I am concerned about those less fortunate than myself & 4.19 & .999 & 4.34 & .777 \\
\hline & $\begin{array}{l}\text { When I serve, I am genuinely concerned about the par- } \\
\text { ticular group I am serving }\end{array}$ & 4.05 & .990 & 4.09 & .878 \\
\hline & I feel compassion toward people in need & 4.29 & .911 & 4.43 & .734 \\
\hline & I feel it is important to help others & 4.41 & .873 & 4.61 & .623 \\
\hline & I can do something for a cause that is important to me & 3.98 & 1.080 & 4.24 & .730 \\
\hline \multirow[t]{5}{*}{ Career function } & $\begin{array}{l}\text { Service-learning can (would) help me to get my foot in } \\
\text { the door in a field where I would like to work }\end{array}$ & 3.97 & .999 & 3.65 & 1.067 \\
\hline & $\begin{array}{l}\text { I can make new contacts that might help my future } \\
\text { career }\end{array}$ & 3.78 & 1.035 & 4.11 & .838 \\
\hline & $\begin{array}{l}\text { Service-learning (would) allow(s) me to explore differ- } \\
\text { ent career options }\end{array}$ & 3.79 & .913 & 3.81 & .948 \\
\hline & $\begin{array}{l}\text { My experience in service-learning will (would) help me } \\
\text { to succeed in my chosen profession }\end{array}$ & 3.70 & 1.025 & 3.69 & .905 \\
\hline & $\begin{array}{l}\text { A service-learning course will (would) look good on my } \\
\text { resume }\end{array}$ & 4.05 & .818 & 4.22 & .818 \\
\hline \multirow[t]{5}{*}{ Social function } & $\begin{array}{l}\text { I have friends who are enrolled in service-learning } \\
\text { courses }\end{array}$ & 3.56 & 1.134 & 2.74 & 1.108 \\
\hline & $\begin{array}{l}\text { People I'm close to want me to enroll in a service-learn- } \\
\text { ing course }\end{array}$ & 3.02 & 1.068 & 2.79 & 1.050 \\
\hline & $\begin{array}{l}\text { People I know share an interest in taking a ser- } \\
\text { vice-learning course }\end{array}$ & 3.58 & .962 & 3.32 & 1.011 \\
\hline & $\begin{array}{l}\text { Others with whom I am close place a high value on } \\
\text { service-learning }\end{array}$ & 3.55 & .902 & 3.31 & 1.049 \\
\hline & $\begin{array}{l}\text { Service-learning is an important activity to the people I } \\
\text { know best }\end{array}$ & 3.55 & .952 & 3.22 & 1.068 \\
\hline \multirow[t]{5}{*}{$\begin{array}{l}\text { Understanding } \\
\text { function }\end{array}$} & $\begin{array}{l}\text { I can (would) learn more about the cause or communi- } \\
\text { ty with which I am working in my service-learning } \\
\text { course }\end{array}$ & 4.25 & .863 & 4.22 & .705 \\
\hline & $\begin{array}{l}\text { Service-learning (would) allow(s) me to gain a new } \\
\text { perspective on things }\end{array}$ & 4.10 & .969 & 4.25 & .785 \\
\hline & $\begin{array}{l}\text { Service-learning (would) let(s) me learn things through } \\
\text { direct, hands-on experience }\end{array}$ & 4.10 & .959 & 4.24 & .810 \\
\hline & I can learn how to deal with a variety of people & 4.14 & .773 & 4.26 & .697 \\
\hline & I can explore my own strengths & 4.07 & .871 & 4.13 & .804 \\
\hline \multirow[t]{5}{*}{$\begin{array}{l}\text { Enhancement } \\
\text { function }\end{array}$} & $\begin{array}{l}\text { Providing community service through my service-learn- } \\
\text { ing course (would) make(s) me feel important }\end{array}$ & 3.91 & .923 & 4.02 & .873 \\
\hline & Service-learning (would) increase(s) my self-esteem & 3.71 & .911 & 3.60 & .915 \\
\hline & Service-learning (would) make(s) me feel needed & 3.61 & 1.021 & 3.64 & .931 \\
\hline & $\begin{array}{l}\text { Service-learning (would) make(s) me feel better about } \\
\text { myself }\end{array}$ & 3.48 & 1.062 & 3.74 & .905 \\
\hline & $\begin{array}{l}\text { A service-learning course is (would be) a way to make } \\
\text { new friends }\end{array}$ & 4.00 & .853 & 4.15 & .712 \\
\hline
\end{tabular}

